\title{
Traditional African economies in conflict with western capitalism 1
}

\section{ABSTRACT}

C M Pauw

Traditional African economies in conflict with western capitalism

Some of the fundamental differences between two economic systems which, by and large, have come into conflict with one another in Africa south of the Sahara are analised, $i$ e traditional African economies and western, capitalist oriented economies. The dire economic conditions prevailing in Africa are the result, to a large extent, of a long history of exploitation and economic disempowerment particularly by western powers. Not all the strategies and programs to counter this poverty are equally appropriate or acceptable. In the meantime a unique coping mechanism is developing, particularly within African Independent Churches which may provide some answers.

\section{INTRODUCTORY REMARKS}

Africa is a continent beset with problems. It is a dichotomised continent. There are conflicting views concerning the land, concerning society, concerning economy. Legal systems differ, human persons and communities are defined and understood in different ways. At the same time the continent is in the grips of an economic crisis and a poverty spiral. In 1985 Africa grew less food per capita than it did twenty years before ${ }^{2}$. Africa was self supporting in terms of food production in 1970. By 1980 it had to import 24 million tons of food ${ }^{3}$.

Traditional African economic systems are part and parcel of an African world and life view. In spite of a century of acculturation, this view continues to influence and condition the hearts and minds of many. Foreign economic systems, introduced mainly from the West, have interacted, or rather come into conflict with the traditional systems. This has resulted in a negative predisposition, particularly concerning western capitalism as it was experienced during the pre-colonial, colonial and postcolonial or post independence stages of history. In fact, capitalism was generally identified with colonialism, imperialism, racism and, in the case of South Africa, apartheid. 
In traditional African societies a key concept variously known as ubuntu (Zulu/Xhosa), botho (Sotho), uMunthu (Chewa), to mention but a few forms, lies very much at the root of the African world and life view. It reflects the African understanding of humanity, human dignity, respect and proper behaviour towards others, particularly seniors. Writing from the Chewa/Tumbuka perspective in Malawi, Musopole describes $u M u n t h u$ as $^{-1}$ human integrity, the essence of being human: "uMunthu is total human integrity which is crucial to cosmic inter-relatedness, harmony and salvation..."5. This human identity has a strong communal dimension. "In community uMunthu is actualised as an inseparable but individuated Munthu"6. Without this integrity a person runs the risk of becoming chinthu cha chabe (a useless, less than human thing). But uMunhu has more than horizontal dimensions. It also links humanity to the entire cosmic reality as well as to the divinity: "To have moral integrity and to be responsible is to participate in the character, therefore the life of God and thus to become a channel of abundant life to the whole creation"7.

In many Southern African languages versions are found of the Xhosa saying Umntu ngumntu ngabantu - a person is a (human) person through other (human) persons. This emphasises the priority of mutuality. What happens to the individual, happens to the whole group and vice versa ${ }^{8}$. This underlines the communal orientation and the corporate personality which characterises humanity in Africa. The centre of identity lies outside the self, in the community. When the individual disintegrates, the community disintegrates and when the community disintegrates, the individual disintegrates 9 . Thus communalism has a determining influence on the human psyche. To endanger the equilibrium would be to endanger life and survival itself. If one aspect of the communal whole is disturbed, the whole of life would be disturbed. All of life and of life power is seen as a continuum of interrelated things ${ }^{10}$.

An individual's behaviour is largely determined, one might even say pre-determined by the dictates of the community. A strong group consciousness hardly allows challenges to the status quo'1. The interests of the community prevail, they determine right and wrong. Ethical principles are spelt out in terms of the well being of the community and of the maintaining of harmony and equilibrium. Thus, taking too much initiative, or succeeding in reaping much better harvests than others, or becoming disproportionately rich through business enterprises, disturbs the cosmic balance: too much life force is being used up by one person, at the expense 
of the rest. Such a person may be suspected of using magic to achieve success. The Zulu would say uyathwala (he is carrying medicine). Sorcery, which involves magic, is abhorred as evil because it uses available powers secretly, and for private purposes. This goes against the interests of the community and of its members ${ }^{12}$. Fear of disturbing the harmony and of incurring the wrath of others therefore inhibits initiative and entrepreneurship, leading to a conservatism, inter alia in agriculture.

The concept of land is also affected. Land is not individually owned, nor can land be sold by one individual to another. Land is the communal possession of all. The chief or leader is the custodian of the land who has the responsibility to designate portions for individual use. When no longer used, or if the land is abused, it reverts back to the leader for redistribution. Every full member of the community has an inalienable right to a reasonable share according to his or her requirements. This right is as secure as a person's membership in the community. It is thus a vested right ${ }^{13}$. In a more profound sense not even the community as a whole owns the land, it belongs to the ancestors ${ }^{14}$. Their graves in the soil of that very land prove their ownership and guarantee the right of their descendants to that land. Blood links human beings to the soil in an intimate identification. Bakare ${ }^{15}$ refers to the fact that when a person is born the umbilical cord is buried in the soil, establishing a kind of existential bond between person and land. Land cannot be owned, it belongs to the people; a free gift of the Creator, just as life itself is a free gift ${ }^{16}$.

The ideology of African socialism, variously expressed in concepts such as Ujamaa in Tanzania and humanism in Zambia, is largely derived from this communalism. In terms of economic activity, trading or exchanging valuables, the upholding of harmony, of equilibrium, of common well being, was of primary importance. In negotiating a deal, the aim would be to achieve optimum equal advantage and satisfaction to both parties. Human dignity and self-respect were to be maintained; there were to be no "losers" nor "winners". The "exploitation of man by man" was constantly condemned by former president Kenneth Kaunda of Zambia. That happened when the "animal in man" became stronger than the spirit of uMunthu.

Equilibrium and harmony with nature was also essential. But nature was seen as a mother, and thus as a source which could supply endlessly in the needs of her children. Conservation or replacing what was used was not contemplated. Water, trees, other resources could be used freely, they would somehow be replaced by "mother nature". At the same time a close relationship existed between man and nature. There was a sense of 
community, of symbiosis. When, for various reasons, this relationship began to disintegrate, people were drawn away from nature ${ }^{17}$. Once again harmony and the sense of communality was placed in jeopardy.

Destruction of harmony and equilibrium, disintegration of a sense of wholeness and of the world and life view leads to a vicious circle. When this corruptive process becomes the style of existence, poverty is the inevitable result ${ }^{18}$. People become fatalistic, apathetic and passive in the face of oppressive conditions ${ }^{19}$. Endemic poverty sets in as a result of a whole series of compounding factors ${ }^{20}$.

\section{WESTERN CONCEPTS OF SOCIETY, ECONOMY, LAND AND THE INDIVIDUAL}

In almost every respect the western world and life view contrasts sharply with that of Africa. Western society is much more individualised. Individual initiative, progress and achievement is greatly admired and encouraged. The role and impact of the community on the life of an individual is therefore much smaller. Cogito ergo sum (Descartes) contrasts with umntu ngumntu ngabantu. Maintaining equilibrium in society is of relatively small concern to the individual. A competitive, ruthlessly selfish spirit is typical 21 . The aim is that of self enrichment, even if it takes place at the expense of others. Success means reaching the top of the ladder, no matter what it takes. The unrestricted pursuit of self-interest is seen not only as acceptable behaviour but as a positive virtue. From infancy the individual is conditioned to excel, to outperform others, to compete, to consider what one has acquired to be one's own by right ${ }^{22}$. And what applies to individuals also determines the attitude of whole communities or nations.

This becomes the basic motive in western (capitalist) economies. Maximum returns, the best "bargain", material progress and capital growth are the goals. There is little concern for the "loser". The principles of uMunthu hardly count. Rather, it is a matter of "winner takes all". The aim is to acquire, develop and utilise as many of the available resources as possible for private or particular gain.

Equally, the attitude towards land differs profoundly. Individual ownership and the right to sell to whoever wishes to buy is generally accepted. Land is a private possession and once the title deeds have been procured, the owner has the right to remove any unwanted occupants and to deny any other person the right to come onto it. The soil is a utility object. It can be manipulated by scientific methods to produce more. The 
aim is maximum gain and profit. Labourers are there for what they can offer in terms of labour. What is invested in them, is done in view of bigger returns. When they no longer can deliver, they must go. This contrasts with employment in traditional societies. There, an employer and a worker, who has accepted the offer, enter into partnership. The employer is regarded as a somewhat special kind of clan chief who has the chiefly function of benefactor, guardian and protector ${ }^{23}$.

\section{COLLISION COURSE}

When these two world and life views came into contact and interact with each other, the results were clearly predictable. Stephen Githumbi24, a Presbyterian pastor from Kenya has succinctly summed it up:

For several centuries the encounter of Africans with people from other parts of the world has left Africa hurt, exploited and deprived. At the heart of African culture is an openness and generosity to the stranger. Tragically, in their encounter with people from more aggressive cultures, the African people have become losers. In welcoming the stranger they have been exploited, enslaved and robbed of their inheritance.

Robert Mugabe, President of Zimbabwe stated this even more forcefully25:

Capitalism did not only plunder our land and other natural resources, thus impoverishing our peasants and making vast communities landless, it also turned a substantial percentage of the population into a poor wage-worker class... The difference between Socialism and Capitalism is, therefore, the difference between quality and inequality, between equity and inequity, between justice and injustice.

Neither are western missions spared. Missionaries were seen as part and parcel of western capitalist expansionism and exploitation. Most missions acquired large tracts of land as private property ${ }^{26}$. Majeke, in The role of missions in conquest ${ }^{27}$, as quoted by Saayman ${ }^{28}$ states that "missionaries came from a capitalist christian civilisation that unblushingly found religious sanctions for inequality, as it does to this day, and whose ministers solemnly blessed its wars of aggression".

It would certainly be possible to make some qualifying remarks to such statements and point out that there is always another side to the picture as far as missions are concerned. Yet the picture of western involvement in Africa over several centuries is a sombre one. Particularly so if viewed from the angle of the "objects" of these endeavors. 
In pre-colonial eras millions of Africans, mostly in the prime of life, were taken away as slaves. This deprived the continent of a vast human potential. The entire slave trading system. as perpetrated by both East and West, the horrors of shipment across oceans, the way slaves were treated and regarded as less than human, need no elaboration.

Full fledged colonialism, which came to Africa just over a century ago, started a second phase of exploitation, this time particularly of natural resources. Africa was haphazardly carved up in the "scramble for Africa". African kingdoms and tribal boundaries were ignored almost without exception. This geopolitical insensitivity doomed future African states to intense struggles for national unity 29 . The aim was to maximally extract from Africa the agricultural, natural and mineral riches which would swell the coffers of the colonial powers and boost the economies and industries in their own countries. In order to achieve this, cheap labour was of prime importance. Policies were devised to ensure abundant supplies of workers. An example is the imposition of hut taxes which were required to be paid in cash. The inevitable failure to do so resulted in captivity and forced labour. In the case of many Malawians, for instance, this entailed a forced ganged march of 180 miles, followed by three months of hard labour on government or private plantations. One month's wages were deducted for tax, and from the rest a person had to provide food for himself. The poor victim eventually, if at all, returned home a "walking skeleton" 30 .

Furthermore, colonial labour policies sapped precapitalist societies of their viability. The continuous absence of part of their labour force led to a decrease in craft production, and a decline in the family production unit. The development of commercial agriculture and of a market for manufactured goods (processed in the colonial home country, often from raw materials originally exported from the colony), led to declining food production in favour of cash crops. For these the best soil would be used. The need for cash income resulted in a growing portion of agricultural producers being marginalised. Surplus population began flocking to urban areas where growing unemployment would ensure an ample source of (cheap) wage workers ${ }^{31}$.

With few exceptions colonies were not industrially developed and were by and large ill prepared, economically and otherwise, for political independence when it came to Africa during the 1960's. The newly independent African states received a heritage through which they were doomed to a never ending economic struggle.

The hope that independence would stem the tide of poverty and oppression soon began to fade ${ }^{32}$. Continued high population growth, 
desertification, war and civil strife, the ever growing debt burden and latterly the structural adjustment policies of the International Monetary Fund and the World Bank, have subjected Africa to an even greater dilemma ${ }^{33}$. Many Africans condemn the power wielded by the World Bank and the International Monetary Fund and the undemocratic manner in which they affect the lives of billions ${ }^{34}$.

This was aggravated by nationals with political and economic power who merely replaced the colonialists and ushered in a new phase of exploitation of their own people ${ }^{35}$. Corruption, self-enrichment by leaders and malappropriation of acquired loans, funds and other forms of aid often left those who most needed help in as poor a state as ever. Transnational corporations have further sapped African economies through polarisation of industrial benefits and the juggling of funds and profits in order to avoid paying taxes and to siphon off whatever profits were being made in any particular country ${ }^{36}$. The north-south division has continued to grow ${ }^{37}$, with Africa becoming more and more peripherised in terms of the global system and the rich North increasingly trading with itself, imposing exorbitant import duties and benefiting from cheap primary commodity imports 38 .

These problems were aggravated in countries where significant white populations were settled, such as Kenya, the Rhodesias (now Zambia and Zimbabwe) and particularly South Africa. That is why, in South Africa today, issues such as economic justice, affirmative action and land rights are being intensely debated. The process of decline in quality of living amongst traditional blacks went hand in hand with the process of gradual deprivation of land.

The problem over land goes back to the earliest negotiations between white government officials or settlers and black tribal leaders. When whites sought to obtain land, they did so in terms of western concepts of individual and private ownership, title deeds and exclusive rights. The other party negotiated in terms of communal ownership of land, vested in the person of the leader who granted rights to the use of the land to individuals under his patronage but did not, and could not, as custodian, sell the land to them as such. But, with a cross drawn on a piece of paper, which the signatory was in any case unable to read, the holder of that document, unknown to the original communal owners, assumed the right to exclusive use of land, implicitly to the exclusion of any further rights the former "owners" had held in terms of communal property. The two parties each negotiated on the basis of a different legal system - Roman Dutch Law and Traditional African Law. This would seem to raise a legitimate 
question: to whom does that particular land now actually belong? It becomes even more complicated when that portion of land has subsequently been sold and resold to any successive number of owners.

As subsistence farmers and cattle owners, black South Africans were formerly largely independent and self-reliant. During the British colonial era the concept of surplus production, a market economy and cash need was created. Blacks became landowners and cultivators. By 1870, in certain areas in the Eastern Cape, at least some were doing better than whites as peasant farmers. Even as sharecroppers, many could still flourish. But once they lost access to the land and had no share in the decisions that shaped their lives, decline was inevitable. The Land Acts of 1913 and of 1936 restricted black land rights to less than $14 \%$ of the surface of South Africa. In the process many blacks were reduced to a community of powerless farm employees or dwellers in the peripheral homelands. They became economically impoverished prisoners of the migrant labour system, often forced off the land of their birth, without even the right to buy ${ }^{39}$. Life became a vicious circle of impotence in peripheral areas succumbing to the potency of a centripetal economy. This drew the work force away, crippled the peripheral economy and channeled the main stream of production away from where the need was ${ }^{40}$. Apartheid laws resulted in the movement of millions of people, with very little compensation. Once the link with the land of their birth and of their ancestors was severed, people tended to become rootless, drifting, disorganised victims of political power struggles ${ }^{41}$. Poverty and a culture of poverty became the life style of people.

\section{THE SEARCH FOR SOLUTIONS}

By and large, solutions are sought in terms of western involvement in development projects or aid schemes. This "development" has in the past mostly been understood in material and economic terms - a reflection of a western-capitalist way of thinking. Development and aid tended to be undertaken from a modernist and positivist point of view. Help was provided from outside and from "above" and the assumption was that in order to develop and progress, non-western communities needed to adapt, become westernised and acculturate to modernity ${ }^{42}$. The terms "developedun(der)developed" often became mere euphemistic replacements for the older "civilised-primitive" distinction. Then the assumption was that there is only one model for a fully developed human being, namely the "Northern Rich Man"43. 
No community or country can exist in isolation or solve its problems on its own. In order to survive in the world of today, adaptation and interaction are essential. Similarly a nostalgic or sentimental hearkening back to old traditional ways of living is hardly realistic. The African traditional communal model should not be romanticised or idealised. Its weaknesses and shortcomings are obvious. Yet to assume that, by adapting and changing to a western type of economy and subscribing to western world and life views, the problems of non-western societies would be solved, is equally unacceptable. Both traditionalism and (western) modernity should be challenged by the Christian faith ${ }^{44}$.

Maritz ${ }^{45}$ criticises the view that the solution lies in changing basic values in a unilinear process towards a universally accepted goal defined as modernisation. The assumption that values can be changed at will and that development will follow in the footsteps of changed values, is not feasible. The western model, even after more than a century, has not taken root in Africa. The question should rather be to what extent "development" meets the definition of the "good life" as understood in Africa. The point of departure should be the existing indigenous values and technical knowledge. The African scientist and developer should grasp the essence of this traditional knowledge and forge it with modern science and technology - without the patronage of western or eastern scientists ${ }^{46}$.

Helping, developing or providing solutions from outside or from "above" will not do. Assistance which is given with the assumption that the helper is the powerful benefactor with whose help the powerless are enabled to adopt the "successful" world and life view of the powerful, is not feasible. This is a danger that even the church can succumb to. When that happens, the role of the church is perceived from a western point of view: the benefactor from outside, sending helpers and instructors ${ }^{47}$, and setting up structures which all too often do not acquire ownership on the part of local people because they are not really involved ${ }^{48}$.

\section{THE CHURCH “DOWN UNDER"}

What the development of Latin American Base Ecclesial Communities has taught us, and what is happening in many African initiated churches has underlined the need for the church and for theology to develop perspectives not from "above" but from "below". Much can and should be done through the involvement of "outside" Christian communities, but what is essentially important for the communities of faith existing within socioeconomically deprived societies, is to play an active and liberating role. 
Christian theology and the church can serve as a catalyst to release people from their dilemmas, to find authentic modern expressions for their traditional cultural heritage as well as to realise their authentic Christian freedom for the future ${ }^{49}$. Nürnberger ${ }^{50}$ emphasises that the church should help to reconstruct collective mindsets, build small committed communities which act as a leaven, create and support healthy families and instil selfconfidence through the Gospel.

In view of the traditional African concept of $u M u n t h u$, Musopole ${ }^{51}$ discusses the concept of Christian uMunthu. Jesus, the Son of Munthu leads to God with us. By restoring health and forgiving sins, He helps people to become Banthu again, thus restoring uMunthu. This constitutes the essence of the Gospel: Munthu was created in the image of God, with divine qualities, through receiving the breath of God. The incarnation in Christ is a re-enactment of our creation and thus of our own re-creation: life means kinship to God. Thus the problem of futility is addressed and the euphemism kulakwa nkwamunthu (to err is human) is in fact nothing less than the deformation of the reality of $u M u n t h u$. The significant point here is that the Gospel enables people to rediscover their essential human integrity, and be reintegrated into a communal fellowship of believers. It restores human values and creates a positive self-image, restored by the grace of God (and in his image!) through faith. The essence of Christian koinonia brings a new sense of belonging and of value. Thus both African traditionalism and westernism are helped to "recognise and maintain the biblical dialectic between the self-assertion of authority and the self-denial of love" and to overcome both the "paralysis of traditionalism and the rat race of modernity" 52 .

The challenge facing those churches which draw their membership from deprived communities is therefore to help their people to find a way not merely to cope with the vicissitudes of the changing world in which they live, but actually to retain or regain the integrity of humanness. This will mean that people are helped to break free from the fetters of traditionalism, but retain the positive values thereof. At the same time they are helped to integrate into the present day world of technology. Nature needs to be objectified without sacrificing ecological integrity. Salvation needs to be understood not only in terms .of "a good life", neither merely in terms of a pietistic gospel, but also holistically as shalom for the whole of creation ${ }^{53}$.

In this respect note should be taken of the way in which the African initiated churches, often called the African Independent Churches are succeeding in helping their people cope with present day situations - often 
more effectively than some of the so-called mainline churches. Initially mainly negative factors were identified as the cause for these churches: they came into being, it was assumed, because of reaction to white oppression and domination and resistance to exploitation and economic marginalisation. There is today a growing recognition that these churches rather reflect a positive response to the total life situation in which people find themselves, as well as a response to the Gospel and to the teachings of the Christian faith as experienced and reinterpreted in an own context ${ }^{54}$. Key concepts in these churches are wholeness and healing in a holisticsalvific sense ${ }^{55}$. Healing of diseases understandably plays a very significant role and involves much more than mere physical healing, taking place at various levels ${ }^{56}$.

Both in urban and in rural areas these churches play an increasingly positive role in empowering their followers, helping them to cope and thus to overcome poverty57. They become "a place to feel at home". They instil a sense of competence and achievement, a sense of mutual support and self improvement ${ }^{58}$. Particularly the Zionist type of churches are providing a new sense of belonging, a new dignity and stability 59 . They create a new communality and even help their followers to develop a new integrated world view to replace the disintegrating traditional world view. In Zimbabwe, for example, a new concept of earth keeping and healing of creation has led to a process of tree planting on an impressive scale ${ }^{60}$.

Independentism is providing a strategy for communities to develop and maintain identity and ubuntu in changing socio-economic contexts and to cope in new and practical ways with the economic vicissitudes of modernised living ${ }^{61}$. Thus they provide a holistic answer to the dilemmas of their people 62 .

\section{CONCLUSION}

As the church wrestles with the problem of economic conflict and poverty in Africa, the so-called mainline churches may discover that for all their sophistication and expertise, they have not succeeded in meeting the needs of their people and of the communities within which they serve as effectively as many of the African Independent Churches are doing. The approaches, methods, theology and holistic ministry of the latter not only provide a fascinating insight into the new world and life view which they are developing, but also present a challenge to the mainline churches to reconsider their methods and theories and learn from their brothers and sisters in the Independent Churches to theologise anew from "below". 


\section{NOTES:}

1 Based on a paper read at the Ninth Conference of the International Association of Mission Studies, Buenos Aires, April 1996.

2 W D Roberts, Africa: A season for hope, Venturo 1985, 113.

3 R Parham, What shall we do in a hungry world?, Birmingham 1988, 26.

4 A C Musopole, "Towards a theological method for Malawi", Journal of Theology for Southern Africa 82 (1993), 42.

$5 \quad$ Musopole, op cit, 41.

$6 \quad$ Ibid.

$7 \quad$ Ibid.

8 W V van Deventer, Poverty and a practical ministry of liberation and development within the context of the traditional Venda concept of man, Unpublished M A thesis, University of the North 1989, 74.

$9 \quad$ Van Deventer, op cit, 76.

$10 \quad$ Van Deventer, op cit, 50, 51 .

11 G C Oosthuizen, "The AIC and the modernisation process" in: G C Ooshuisen (Ed), Religion alive: Studies in the new movements and Indigenous Churches in Southern Africa, Johannesburg 1986, 227.

12 K Nürnberger, "A consideration of the structure of economic society in South Africa”, in: W S Vorster (Ed), Church and industry, Pretoria 1983, 19.

13 M Manley, "Land and soil: A European commodity in Shona traditional perspective”, Journal for the Study of Religion 8/1 (1995), 31, 32.

14 P G Batchelor \& H R Boer, Theology and rural development in Africa, Grand Rapids 1966, 11.

15 S Bakare, My right to land - in the Bible and in Zimbabwe, Harare 1994.

16 Manley, op cit, 45.

17 Van Deventer, op cit, 83.

18 See Van Deventer, op cit, 51, 52. 
19 S Githumbi, “Development, missiology and Africa's cities”, Urban Mission 12/3 (1995), 23.

20 See S D Maluleke, Struggle against poverty, Pretoria 1994, 7-11.

21 Nürnberger, “Economic society”, 20.

22 Nürnberger, “Economic society”, 19.

23 F Fisher, "Class consciousness among colonised workers in South Africa", in: $\mathrm{L}$ Schlemmer and E Webster (Eds), Change, reform and economic growth in South Africa, Johannesburg 1978, 206.

24 Githumbi, op cit, 24.

25 In $\mathrm{V}$ de Waal, The politics of reconciliation: Zimbabwe's first decade, Trenton 1990, 118. See in this respect J du Preez, Die aantrekkingskrag van die Marxisme vir die Derde Wêreld, Cape Town 1988, passim.

26 W Saayman, Christian mission in South Africa, Pretoria 1991, 29.

27 N Majeke, The role of missions in conquest, Cumberwood 21986, 4.

28 Saayman, op cit, 25.

29 Parham, op cit, 75.

30 See C M Pauw, Mission and church in Malawi. The history of the Nkhoma Synod of the Church of Central Africa, Presbyterian 1889-1962, D Th dissertation, University of Stellenbosch 1980, 127-138, for details of the hut tax and labour system and its effects in Central Malawi.

31 D D Cordell \& J W Gregory, African population and capitalism - historical perspectives, Wisconsin 1987, 28, 29.

32 Githumbi, op cit, 24.

33 O B Sichone, "Africa in Global Perspective. Will Africa enter the $21 \mathrm{st}$ century?" in: O B Sichone, et al (Eds), Africa and the new world order, Potchefstroom 1994, 2-3.

34 See M J Lamola, The international monetary system and poverty in Africa: $A$ challenge to Christian mission (Studies and reports by the Institute for Theological and Interdisciplinary Research, Ecumenical Foundation of Southern Africa), Bellville 1993, 5-10, 16. 
35 Githumbi, op cit, 24.

36 See J B Stewart, Joint action for economic development in Southern Africa after apartheid, Stellenbosch 1994, 6.

37 J Nyerere, Africa's development in a global perspective (Studies and reports by the Institute for Theological and Interdisciplinary Research, Ecumenical Foundation of Southern Africa), Bellville 1994, 4.

38 B Turok, "Africa's peripheralization in the global system", in: O B Sichone (Ed), Africa and the new world order, Potchefstroom 1994, 9, 10.

39 E C D Bruwer, "From subsistence cultivator, to peasant, to farm worker", Missionalia 16/2 (1988), 59-60; M Nash, Rural poverty challenges the church, Johannesburg 1984, 50.

40 Cf Nürnberger, "Economic Society", 11-17.

41 E Bruwer, Beggars can be choosers. In search of a better way out of poverty and dependence, Pretoria 1994, 91.

42 K Nürnberger, "The task of the church concerning the economy in a postapartheid South Africa”, Missionalia 22/2 (1994), 143.

43 De Waal, op cit, 24.

44 Nürnberger, Missionalia 22/2 (1994), 143.

45 C J Maritz, Response to G C Oosthuizen, "Africa's social and cultural heritage in a new era", Africa Insight 17/2 (1987), 121, 139.

46 Maritz, op cit, 139; See J J Kritzinger, “African Indigenous Churches and development", Skrif en Kerk 11/1 (1990), 53-54.

47 So with $\mathrm{C}$ Kreider, The rich and the poor: A Christian perspective on global economics, Scotdale 1987, 82.

48 H Mashabela, Mekhukhu: Urban African cities of the future, Johannesburg 1990, 50.

49 J A van Wyk, "Liberation theology in the African context", in: J W Hofmeyr \& W S Vorster (Eds), New faces of Africa, Pretoria 1984, 187-188.

50 K Nümberger, An economic vision for South Africa. The task of the church in the post apartheid economy, Pietermaritzburg 1994, 54.

$51 \quad$ Musopole, op cit, 42. 
52 Nürnberger, “Missionalia 22/2 (1994), 145.

53 See Kritzinger, op cit, 62.

54 M Pauw, "African Independent Churches as a 'people's response' to the Christian message”, Journal for the Study of Religion 8/1 (1995), 9-19.

55 See G W S van Rooyen, Heel-heid en heil-saamheid as sleutelkonsepte vir die verstaan van die Onafhanklike Afrika Kerke in Suidelike Afrika, D Th dissertation, University of Stellenbosch 1993, passim.

56 See C M Pauw, "Siekte en geneeskundige dienste teen die agtergrond van die tradisionele Afrika lewens- en wêreldbeskouing”, Acta Theologica 14/1 (1994), 65-67.

57 R W Sharland, "The distinctive role of African instituted churches in rural development", in: S Nussbaum (Ed), Freedom and interdependence. (Papers presented at the Conference on Ministry in partnership with African Independent Churches, April 1993, Johannesburg), Nairobi 1994, 71, 74; See $M$ L Daneel, "African Independent Churches face the challenge of environmental ethics”, Missionalia 21/3 (1993), 317.

$58 \quad$ Oosthuizen, op cit, 1986, 232-234.

$59 \mathrm{~J}$ de Wet, "Social change, resistance and worldview of a community in the Transkei", in: G C Oosthuizen, M C Kitshoff \& S W D Dube (Eds), AfroChristianity at the grassroots, Leiden 1994, 160.

60 See Daneel, op cit, 318ff.

61 Daneel, op cit, 317; G C Oosthuizen, "De Onafhankelijke Afrikaanse Kerken in het nieuwe Zuid-Afrika”, Wereld en Zending 24/2 (1995), 54.

62 Oosthuizen, op cit, 1995, 49, 50. 